\title{
The Trump administration and the Neoliberal Project
}

\author{
Wesley C. Marshall ${ }^{1}$
}

The 2016 election of Donald Trump has been one of the most controversial in the recent political history of the United States. While many have correctly described and criticized his leadership as a president, they tend to focus these issues within the framework of the worrying and unique personality traits of the current president. This article will take a different approach, and attempts to understand Donald Trump as man of his times, in many ways a singularly precise personification of today's neoliberal inspired zeitgeist. The article will focus on four elements of the neoliberal project: "post truth", disaster capitalism, individualism, and the dumbing down of society. [Article copies available for a fee from The Transformative Studies Institute. E-mail address: journal@transformativestudies.org Website: http://www.transformativestudies.org (C2018 by The Transformative Studies Institute. All rights reserved.]

KEYWORDS: Government Policy and Regulation, Government Policy, Crisis Management.

Shortly before the 2016 presidential election, most election watchers considered Hillary Clinton the overwhelming favorite to become the 45th president of the United States (US). However, in a contest of historically unpopular candidates, it was Donald Trump that won the presidency if not the popular vote. While the failure of many experts once again proved that predicting the future is a difficult task, many found humor and irony in the fact that the 1989 movie Back to the Future II predicted an alternate world in which Donald Trump would be president and the Chicago Cubs would win the world series.

\footnotetext{
${ }^{1}$ Wesley C. Marshall, Ph.D., is a professor at the Universidad Autónoma Metropolitana - Iztapalapa. He is on the editorial board of Ola Financiera and the editorial advisory board of the Review of Political Economy, and is associate editor of the International Journal of Political Economy. He is the author of the 2011 book Mexico desbancado: causas y consecuencias de la pérdida de la banca nacional. Address correspondence to: Dr. Wesley C. Marshall, Av. San Rafael Atlixco 186, Leyes de Reforma 1ra Secc, 09340 Ciudad de México, CDMX, Mexico. Address correspondence to: Wesley C. Marshall, e-mail: wesleycmarshall@gmail.com.
} 